\title{
Practical Implication of Chromatographic Method for Estimation of Aceclofenac and Pregabalin in Bulk and Pharmaceutical Dosage Forms
}

\author{
Hitendrakumar D. Gelani, Payal P. Chauhan, and Samir K. Shah \\ Department of Pharmaceutical Chemistry, Sardar Patel College of Pharmacy, Bakrol, Anand, Gujarat 388120, India \\ Correspondence should be addressed to Hitendrakumar D. Gelani; hitendragelani13@gmail.com
}

Received 21 July 2014; Accepted 29 October 2014; Published 16 December 2014

Academic Editor: Toyohide Takeuchi

Copyright (C) 2014 Hitendrakumar D. Gelani et al. This is an open access article distributed under the Creative Commons Attribution License, which permits unrestricted use, distribution, and reproduction in any medium, provided the original work is properly cited.

\begin{abstract}
Background. Aceclofenac and Pregabalin in combination significantly reduce pain as compared to individual drug in chronic low back pain. Literature reveals that all the reported spectrophotometric methods either need tedious extraction procedures, do not offer high sensitivity, use nonspecific reagent, or recommend the measurement of absorbance in the near UV region where interference most probably occurs that does not offer suitable linearity range. Result. A selective, sensitive, accurate, and precise, high performance liquid chromatographic method with UV detector analysis of Aceclofenac and Pregabalin was investigated. Good chromatographic separation was achieved using an ODS-BP hypersil $\mathrm{C}_{18}$ column $(250 \mathrm{~mm} \times 4.6 \mathrm{~mm}$, i.d., $5 \mu \mathrm{m})$ and a mobile phase consisting of $0.05 \mathrm{M}$ phosphate buffer $\left(\mathrm{KH}_{2} \mathrm{PO}_{4}\right)(\mathrm{pH} 6.0):$ methanol $(60: 40, \mathrm{v} / \mathrm{v})$ at a flow rate $1 \mathrm{~mL} / \mathrm{min}$. The ultraviolet detector was set at wavelength $218 \mathrm{~nm}$. Retention time for Aceclofenac and Pregabalin was found to be 3.220 and 5.910 min, respectively. Rectilinear relationship with good regression coefficients 0.999 and 0.999 was found over the concentration ranges of 5-25 $\mu \mathrm{g} / \mathrm{mL}$ and $3.75-18.75 \mu \mathrm{g} / \mathrm{mL}$ for ACF and PGB, respectively, with detection limits 0.64 and $0.35 \mu \mathrm{g} / \mathrm{mL}$ and quantitation limits 1.95 and $1.06 \mu \mathrm{g} / \mathrm{mL}$. Conclusion. The mean percentage recoveries were in the range of 98.45-100.08 and 99.69-100.48 for ACF and PGB, respectively. The developed method was successfully applied to the analysis of the drugs in their commercial tablets.
\end{abstract}

\section{Introduction}

ACF is 2-[2-[2-[(2,6-dichlorophenyl) amino] phenyl] acetyl] oxy acetic acid. It is a nonsteroidal anti-inflammatory drug with good analgesic effect [1] (Figure 1). PGB is S-3-(amino methyl)-5-methylhexanoic acid. It is an anticonvulsant drug for neuropathic pain and adjunct for partial seizures. It can be used in generalised anxiety disorders [2] (Figure 2). ACF is official in British Pharmacopoeia, 2009, Indian Pharmacopoeia, 2010, and European Pharmacopoeia, 2005 [1, 3, 4]. PGB is official in Indian Pharmacopoeia, 2010 [1]. The literature survey revealed that few analytical methods have been published concerning the simultaneous estimation of ACF and PGB either alone or in combination with other drugs, namely, spectrophotometric $[5,6]$ and chromatographic [7-9] methods for ACF and spectrophotometric [10], chromatographic [11], and also spectrofluorimetric [12,
13] methods for PGB. Spectrofluorimetries are not available in many labs. Regarding spectrophotometric methods for determination of PGB, some of them do not offer high sensitivity or need tedious extraction procedures. Meanwhile, some of the spectrophotometric methods recommended the measurement of absorbance in the near UV region where interference most probably occurs or use nonspecific reagent (potassium iodide/potassium iodate) that does not offer suitable linearity range. Therefore, our target was to develop a rapid, simple, efficient, and selective method for the analysis of ACF and PGB in pharmaceutical formulation.

\section{Experimental}

2.1. Reagents and Materials. ACF and PGB pure API were procured as a gratis sample from West Coast Pharmaceutical 
<smiles>O=C(O)COC(=O)Cc1ccccc1Nc1c(Cl)cccc1Cl</smiles>

Figure 1: Structure of ACF.<smiles>CC(C)C[C@H](CN)CC(=O)O</smiles>

FIgURe 2: Structure of PGB.

Works, Ahmedabad. All employed chemicals were of HPLC grade.

2.2. Instruments. The instruments were HPLC (Analytical Technologies), S 1122 series pump, 2203 UV-Visible detector, and Rheodyne injector $(20 \mu \mathrm{L})$. Swisher electronic balance was used for weighing the samples.

2.3. Chromatographic Conditions. A hypersil $\mathrm{C}_{18}(250 \times 4.6 \mathrm{~mm})$ chromatographic column and mobile phase consisting of phosphate buffer (pH-6.0): methanol (60:40) were used. Flow rate was maintained at $1 \mathrm{~mL} / \mathrm{min}$ and effluents were monitored at $218 \mathrm{~nm}$. The sample was injected using $20 \mu \mathrm{L}$ Rheodyne injector. Freshly prepared samples were used at the time of use.

2.4. Preparation of Standard Stock Solution. Accurately weighed quantity of ACF (100 mg) and PGB (75 mg) was transferred into two separate $100 \mathrm{~mL}$ volumetric flasks, dissolved, and diluted up to mark with methanol to get strength of $1000 \mu \mathrm{g} / \mathrm{mL}$ of $\mathrm{ACF}$ and $750 \mu \mathrm{g} / \mathrm{mL}$ of PGB.

2.5. Preparation of Working Standard Solution. Transfer $10 \mathrm{~mL}$ of stock solution of ACF and PGB into two separate $100 \mathrm{~mL}$ volumetric flasks and dilute up to mark with methanol to get strength of $100 \mu \mathrm{g} / \mathrm{mL}$ of ACF and $75 \mu \mathrm{g} / \mathrm{mL}$ of PGB.

2.6. Preparation of Combined Standard Solution of Aceclofenac and Pregabalin. Accurately weighed quantities of Aceclofenac $(100 \mathrm{mg})$ and Pregabalin $(750 \mathrm{mg})$ were transferred into $100 \mathrm{~mL}$ volumetric flasks. They were dissolved and diluted up to the mark with methanol to give a combined stock solution $(1000 \mu \mathrm{g} / \mathrm{mL})$ of Aceclofenac and $(750 \mu \mathrm{g} / \mathrm{mL})$ of Pregabalin. Stock solution $(10 \mathrm{~mL})$ was transferred in $100 \mathrm{~mL}$ volumetric flask and diluted up to mark with methanol to obtain combined working standard solution $(100 \mu \mathrm{g} / \mathrm{mL})$ of
Aceclofenac and $(75 \mu \mathrm{g} / \mathrm{mL})$ of Pregabalin. This solution was used to prepare standard solution for linearity.

2.7. Calibration Curve for ACF and PGB. The combined solution of Aceclofenac and Pregabalin ranging from 5 to $25 \mu \mathrm{g} / \mathrm{mL}$ and 3.75 to $18.75 \mu \mathrm{g} / \mathrm{mL}$ was prepared by pipetting out $0.5,1.0,1.5,2.0$, and $2.5 \mathrm{~mL}$ of the combined working standard solution of Aceclofenac $(100 \mu \mathrm{g} / \mathrm{mL})$ and Pregabalin $(75 \mu \mathrm{g} / \mathrm{mL})$ into series of $10 \mathrm{~mL}$ volumetric flasks and the volume was adjusted to mark with mobile phase.

Chromatogram of each solution was recorded. The graph of area versus respective concentration was plotted.

\section{Method Validation}

3.1. Specificity. Chromatograms of standard and sample solutions of Aceclofenac and Pregabalin were compared.

3.2. Linearity and Range. The linearity response was determined by analyzing 5 independent levels of calibration curve in the range of $5-25 \mu \mathrm{g} / \mathrm{mL}$ and $3.75-18.75 \mu \mathrm{g} / \mathrm{mL}$ for ACF and $\mathrm{PGB}$, respectively.

3.3. Accuracy. Accuracy of the method was determined in terms of \% recovery of standard. Recovery studies were carried out by addition of standard drug solution at the level of $50 \%, 100 \%$, and $150 \%$ to the preanalyzed sample. In this method the known concentration standard drug was added to the assay sample.

3.4. Precision. Precision of the method was determined by performing repeatability, intraday precision, and interday precision. In repeatability study, one concentration of both drugs was analysed six times. In intraday precision, three replicates of three concentrations were analyzed at short interval of time. In interday precision, three replicates of three concentrations were analyzed at three consecutive days.

3.5. LOD and LOQ. The LOD and LOQ may be calculated as

$$
\begin{aligned}
& \mathrm{LOD}=3.3 \times\left(\frac{\mathrm{SD}}{\text { Slope }}\right), \\
& \mathrm{LOQ}=10 \times\left(\frac{\mathrm{SD}}{\text { Slope }}\right),
\end{aligned}
$$

where $\mathrm{SD}$ is the standard deviation of $Y$-intercept of 5 calibration curves. Slope is the mean slope of the 5 calibration curves.

3.6. Robustness. Combined standard solutions of Aceclofenac $(15 \mu \mathrm{g} / \mathrm{mL})$ and Pregabalin $(7.5 \mu \mathrm{g} / \mathrm{mL})$ were prepared and analyzed changing mobile phase, flow rate, and $\mathrm{pH}$ by measuring the corresponding responses 3 times.

3.7. Assay of Pharmaceutical Formulation. Twenty tablets were weighed and powdered. The tablet powder equivalent to $100 \mathrm{mg}$ of Aceclofenac or $75 \mathrm{mg}$ of Pregabalin was transferred to a $100 \mathrm{~mL}$ volumetric flask, dissolved, and diluted 


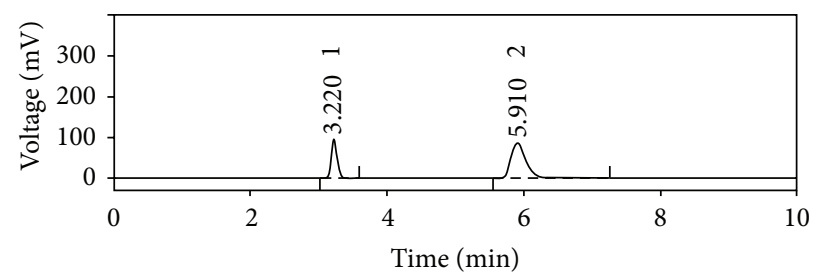

FIGURE 3: Chromatogram of Aceclofenac $(15 \mu \mathrm{g} / \mathrm{mL})$ and Pregabalin $(11.25 \mu \mathrm{g} / \mathrm{mL})$ in buffer $(\mathrm{pH}-6.0)$ : methanol $(60: 40)$.

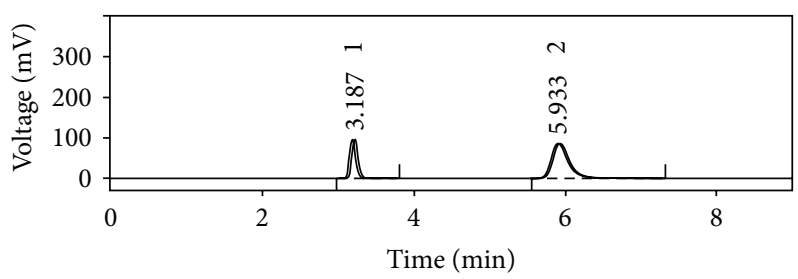

FIGURE 4: Overlain chromatograms of standard and sample solutions of Aceclofenac and Pregabalin.

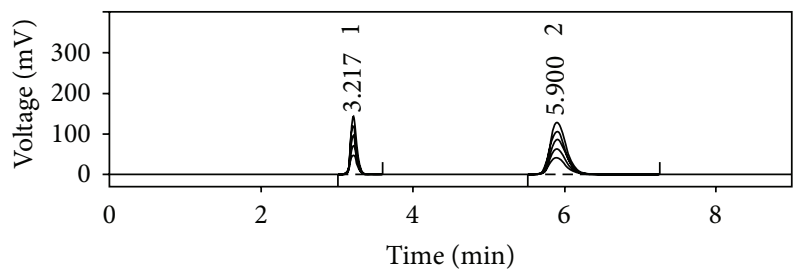

Figure 5: Overlain chromatogram of Aceclofenac (5-25 $\mu \mathrm{g} / \mathrm{mL})$ and Pregabalin $(3.75-18.25 \mu \mathrm{g} / \mathrm{mL})$.

up to mark with methanol to get strength of $1000 \mu \mathrm{g} / \mathrm{mL}$ Aceclofenac or $750 \mu \mathrm{g} / \mathrm{mL}$ Pregabalin (stock solution). The solution was filtered through Whatman filter paper number 41 and first few $\mathrm{mL}$ of filtrate was discarded. From stock solution, $10 \mathrm{~mL}$ solution was transferred to $100 \mathrm{~mL}$ volumetric flask and volume is adjusted to the mark with methanol to get strength of $100 \mu \mathrm{g} / \mathrm{mL}$ Aceclofenac and $75 \mu \mathrm{g} / \mathrm{mL}$ Pregabalin (working solution). From working solution, $1.0 \mathrm{~mL}$ solution was transferred to $10 \mathrm{~mL}$ volumetric flask and volume is adjusted to the mark with mobile phase to get strength of $10 \mu \mathrm{g} / \mathrm{mL}$ Aceclofenac and $7.5 \mu \mathrm{g} / \mathrm{mL}$ Pregabalin. Chromatogram of this solution was taken and the concentration of each drug was calculated using regression equation.

\section{Result and Discussion}

4.1. Method Development and Optimization of Chromatographic Conditions. The mobile phase phosphate buffer $(\mathrm{pH}-$ $6.0)$ : methanol $(60: 40 \mathrm{v} / \mathrm{v})$ was found to be satisfactory and gave two symmetric and well-resolved peaks for ACF and PGB (Figure 3). The retention time for ACF and PGB was 3.220 and $5.910 \mathrm{~min}$, respectively. The resolution between ACF and PGB was found to be 9.779, which indicates good separation of both of the compounds. The asymmetric factors for ACF and PGB were 1.333 and 1.569, respectively. The mobile phase flow rate was maintained at $1 \mathrm{~mL} / \mathrm{min}$. From the literature review $218.0 \mathrm{~nm}$ was selected as a detection wavelength.

\section{Method Validation}

5.1. Specificity. Chromatograms of standard and sample solutions of Aceclofenac and Pregabalin were compared (Figure 4).

5.2. Linearity and Range. The calibration curve for ACF and PGB was found to be linear in the concentration range of 5$25 \mu \mathrm{g} / \mathrm{mL}$ and 3.75-18.75 $\mu \mathrm{g} / \mathrm{mL}$, respectively (Figure 5).

5.3. Accuracy (Standard Addition Method). Result obtained reveals that \% recovery of ACF and PGB was found to be 98.45-100.08 and 99.69-100.48, respectively (Table 1).

5.4. Precision. For repeatability, \% CV was found to be 1.32 and 1.55 for ACF and PGB, respectively. For intraday precision, \% CV was found to be $0.91-1.29$ and $0.72-1.07$ for $\mathrm{ACF}$ and $\mathrm{PGB}$, respectively. For interday precision, \% CV was found to be $1.32-1.98$ and $0.94-1.77 \%$ for ACF and PGB, respectively.

5.5. Robustness. Variation in the flow rate, mobile phase, and $\mathrm{pH}$ has been made to the analytical method in order to evaluate and measure the capacity of the method to remain unaffected by such variations. The $\% \mathrm{CV}$ was found to be less than 2 (Tables 2, 3, and 4). 
TABLE 1: Accuracy (\% recovery study) $(n=3)$.

\begin{tabular}{|c|c|c|c|c|c|c|c|}
\hline \multicolumn{4}{|c|}{$\mathrm{ACF}$} & \multicolumn{4}{|c|}{ PGB } \\
\hline Conc. $(\mu \mathrm{g} / \mathrm{mL})$ & $\%$ of std. drug added & $\begin{array}{c}\% \text { recovery } \\
(\text { mean } \pm \text { SD })\end{array}$ & $\% \mathrm{CV}$ & Conc. $(\mu \mathrm{g} / \mathrm{mL})$ & $\%$ of std. drug added & $\begin{array}{c}\text { \% recovery } \\
(\text { mean } \pm S D)\end{array}$ & $\% \mathrm{CV}$ \\
\hline \multirow{3}{*}{10} & 50 & $98.89 \pm 0.68$ & 0.69 & \multirow{3}{*}{7.5} & 50 & $100.48 \pm 1.81$ & 1.81 \\
\hline & 100 & $98.45 \pm 0.77$ & 0.78 & & 100 & $99.69 \pm 1.74$ & 1.75 \\
\hline & 150 & $100.08 \pm 0.73$ & 0.72 & & 150 & $99.99 \pm 1.40$ & 1.40 \\
\hline
\end{tabular}

TABLE 2: Change in flow rate $(n=3)$.

\begin{tabular}{lccc}
\hline Drug & Flow rate $(\mathrm{mL})$ & Mean area $\pm \mathrm{SD}$ & \% CV \\
\hline \multirow{2}{*}{ Aceclofenac $(15 \mu \mathrm{g} / \mathrm{mL})$} & 0.95 & $1362.80 \pm 10.54$ & 0.77 \\
& 1.05 & $1281.76 \pm 14.59$ & 1.14 \\
\hline \multirow{2}{*}{ Pregabalin $(11.25 \mu \mathrm{g} / \mathrm{mL})$} & 0.95 & $577.58 \pm 5.31$ & 0.92 \\
& 1.05 & $543.88 \pm 6.70$ & 1.23 \\
\hline
\end{tabular}

TABLE 3: Change in mobile phase combination $(n=3)$.

\begin{tabular}{lccc}
\hline Drug & Mobile phase composition & Mean area \pm SD & $\%$ CV \\
\hline \multirow{2}{*}{ Aceclofenac $(15 \mu \mathrm{g} / \mathrm{mL})$} & $58.8: 41.2$ & $1340.04 \pm 23.94$ & 1.79 \\
& $61.2: 38.8$ & $1275.57 \pm 21.35$ & 1.67 \\
\hline \multirow{2}{*}{ Pregabalin $(11.25 \mu \mathrm{g} / \mathrm{mL})$} & $58.8: 41.2$ & $569.37 \pm 7.93$ & 1.39 \\
& $61.2: 38.8$ & $542.44 \pm 7.80$ & 1.44 \\
\hline
\end{tabular}

TABLE 4: Change in $\mathrm{pH}(n=3)$.

\begin{tabular}{lccc}
\hline Drug & $\mathrm{pH}$ & Mean area \pm SD & \% CV \\
\hline \multirow{2}{*}{ Aceclofenac $(15 \mu \mathrm{g} / \mathrm{mL})$} & 5.9 & $1341.40 \pm 24.68$ & 1.84 \\
\hline \multirow{2}{*}{ Pregabalin $(11.25 \mu \mathrm{g} / \mathrm{mL})$} & 6.1 & $1254.06 \pm 19.24$ & 1.53 \\
\hline
\end{tabular}

TABLE 5: Assay results of marketed formulation $(n=5)$.

\begin{tabular}{lccccc}
\hline & ACF & & PGB \\
Label claim $(\mathrm{mg})$ & Amount found $(\mathrm{mg})$ & $\%$ assay \pm SD & Label claim $(\mathrm{mg})$ & Amount found (mg) & $\%$ assay \pm SD \\
\hline 100 & 98.50 & $98.79 \pm 1.41$ & 75 & 74.25 & $99.39 \pm 1.68$ \\
\hline
\end{tabular}

TABLE 6: Summary of validation parameters.

\begin{tabular}{lcc}
\hline Parameter & Aceclofenac & Pregabalin \\
\hline Linearity & & $y=36.05 x+133.4$ \\
$\quad$ Regression equation & $y=64.93 x+306.8$ & 0.999 \\
Regression coefficient $\left(R^{2}\right)$ & 0.999 & $3.75-18.75$ \\
Range $(\mu \mathrm{g} / \mathrm{mL})$ & $5-25$ & $99.69-100.48$ \\
Accuracy $(\%$ mean recovery) $(n=3)$ & $98.45-100.08$ & 1.55 \\
Precision $(\% \mathrm{CV})$ & & $0.72-1.07$ \\
Repeatability $(n=6)$ & 1.32 & $0.94-1.77$ \\
Intraday precision $(n=3)$ & $0.91-1.29$ & 0.35 \\
Interday precision $(n=3)$ & $1.32-1.98$ & 1.06 \\
LOD $(\mu \mathrm{g} / \mathrm{mL})$ & 0.64 & Complied \\
LOQ $(\mu \mathrm{g} / \mathrm{mL})$ & 1.95 & Complied \\
Specificity & Complied & Complied \\
Robustness & & \\
\hline
\end{tabular}


5.6. LOD and LOQ. LOD was found to be 0.64 and $0.35 \mu \mathrm{g} / \mathrm{mL}$ for ACF and PGB, respectively. LOQ was found to be 1.95 and $1.06 \mu \mathrm{g} / \mathrm{mL}$ for ACF and PGB, respectively.

5.7. Assay of Marketed Formulation. Percentage purity of ACF and PGB was found to be $98.79 \%$ and $99.39 \%$ for ACF and PGB, respectively (Table 5). A summary of validation parameters can be found in Table 6 .

\section{Conclusion}

The proposed chromatographic method was found to be simple, sensitive, accurate, and precise for determination of ACF and PGB in combined dosage form. The common excipients and additives which are usually present in the combined dosage form do not interfere in the analysis of ACF and PGB in the method; hence it can be conveniently adopted for routine quality control analysis of the drugs in combined dosage form.

\section{Conflict of Interests}

The authors declare that there is no conflict of interests regarding the publication of this paper.

\section{Acknowledgments}

The authors extended gratitude to the institute (Sardar Patel College of Pharmacy, Bakrol, Anand) for providing great facility and support to complete their research work. The authors also express thankfulness to West Coast Pharmaceutical Work, Ahmedabad, Gujarat, India, for providing generous sample of Aceclofenac and Pregabalin for carrying out the research work.

\section{References}

[1] Indian Pharmacopoeia, Delhi, India, 2010.

[2] Indian Pharmacopoeia 1960, New Delhi, India, 2010.

[3] British Pharmacopoeia, Stationary Office, Medicines and Healthcare Products Regulatory Agency, London, UK, 64216424, 2010.

[4] European Pharmacopoeia, "Europe," 910, 2011.

[5] R.Shah, C. Magdum, S. K. Patil, D. K. Chougule, and N. Naikwade, "Validated Spectroscopic method for estimation of aceclofenac from tablet formulation," Research Journal of Pharmacy and Technology, vol. 1, no. 4, pp. 430-432, 2008.

[6] A. D. Nikam, S. S. Pawar, and S. V. Gandhi, "Simultaneous spectrophotometric estimation of aceclofenac and paracetamol," Asian Journal of Chemistry, vol. 19, pp. 5075-5080, 2007.

[7] K. A. Shaikh, A. T. Patil, and A. B. Ingole, "Sensitive LC method for the simultaneous determination of diacerein and aceclofenac in tablet dosage form," International Journal of Industrial Chemistry, vol. 3, p. 3, 2012.

[8] J. R. Jain, D. R. Shah, S. A. Shah, and R. S. Chauhan, "RPHPLC method for simultaneous estimation of drotaverine hydrochloride and aceclofenac in their combined tablet dosage form," Der Pharma Chemica, vol. 3, no. 4, pp. 245-252, 2011.
[9] V. V. Bharekar, T. S. Mulla, and S. S. Yadav, "Validated HPTLC method for simultaneous estimation of Rabeprazole Sodium and Aceclofenac in bulk drug and formulation," International Journal of Comprehensive Pharmacy, vol. 5, pp. 1-4, 2011.

[10] M. K. Oommen and S. C. Eapen, "UV-Vis spectrophotometric method for estimation of Pregabalin and methylcobalamin in bulk and capsule dosage form," International Journal of Pharmaceutical Research and Life Scences, vol. 1, pp. 115-124, 2013.

[11] S. K. Mishra, B. M. Gurupadhyya, and S. Verma, "Stability indicating RP-HPLC method for determination of Pregabalin using ICH guidelines," International Journal of Natural Product Science, vol. 1, pp. 115-119, 2012.

[12] A. Önal and O. Sagirli, "Spectrophotometric and spectrofluorimetric methods for the determination of pregabalin in bulk and pharmaceutical preparation," Spectrochimica Acta Part A: Molecular and Biomolecular Spectroscopy, vol. 72, no. 1, pp. 6871, 2009.

[13] M. I. Walash, F. Belal, N. El-Enany, and M. H. El-Maghrabey, "Simple and sensitive spectrofluorimetric method for the determination of pregabalin in capsules through derivatization with fluorescamine," Luminescence, vol. 26, no. 5, pp. 342-348, 2011. 

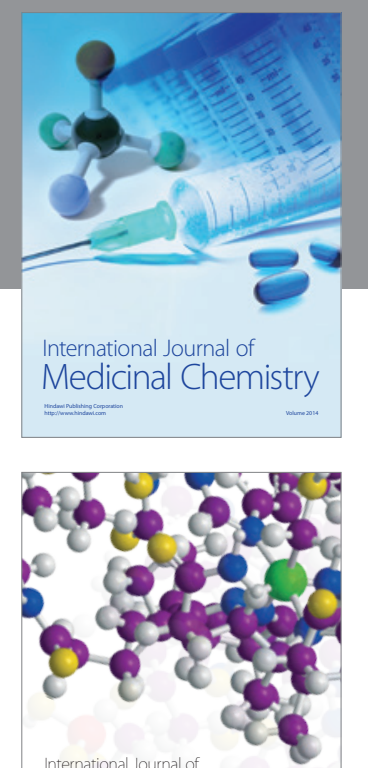

\section{Carbohydrate} Chemistry

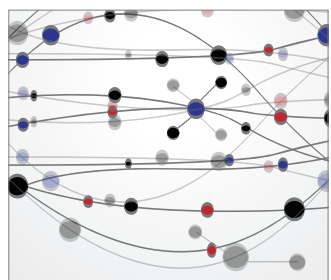

The Scientific World Journal
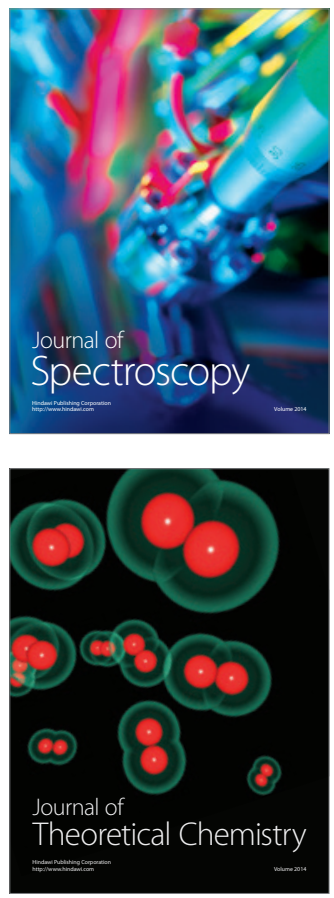
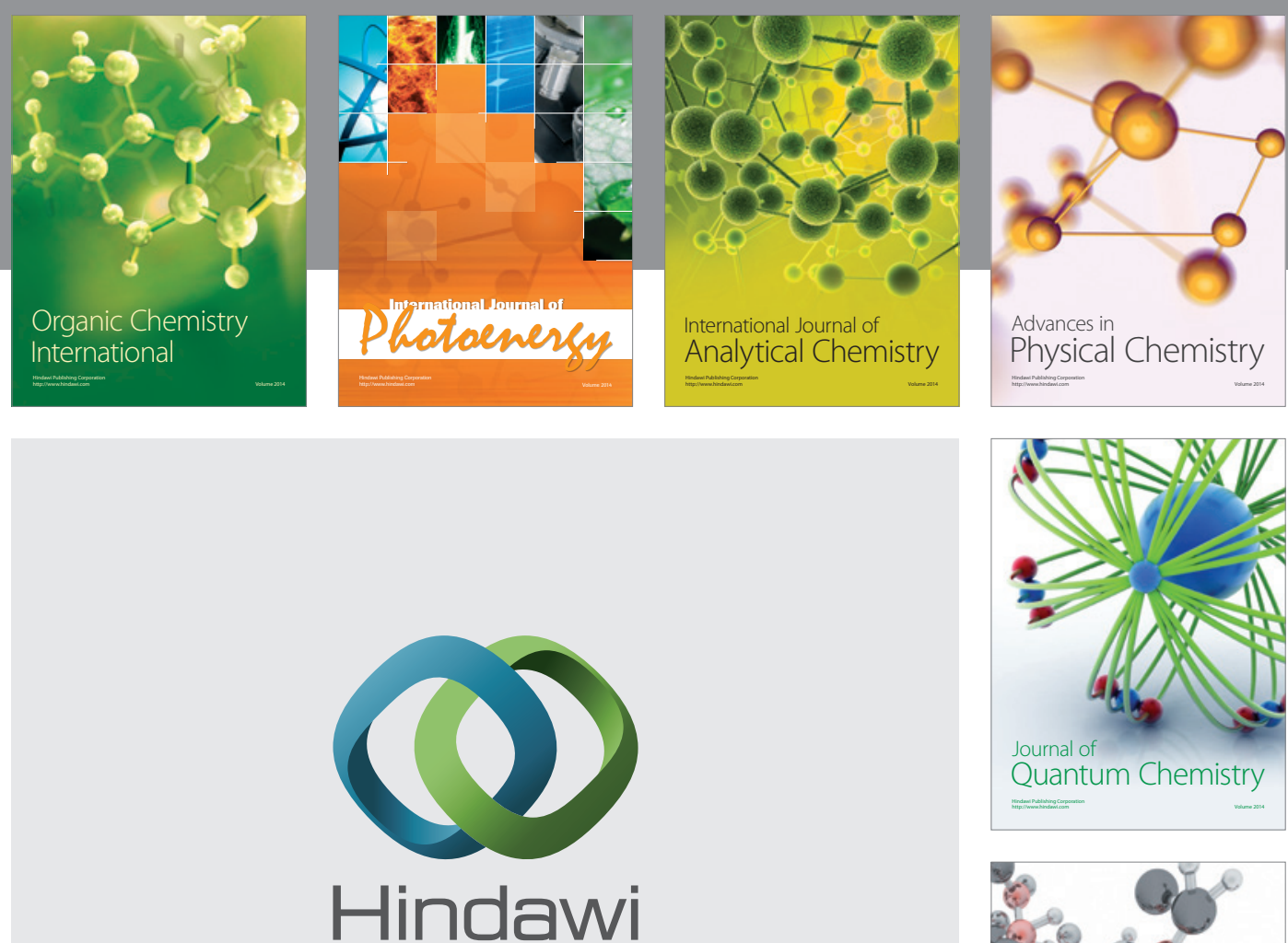

Submit your manuscripts at

http://www.hindawi.com

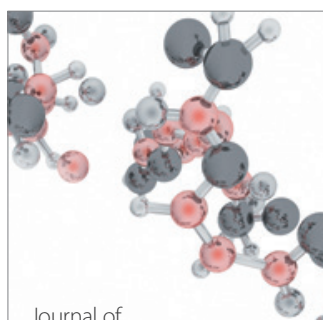

Analytical Methods

in Chemistry

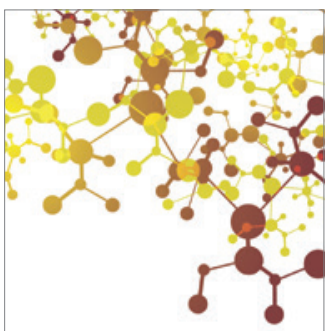

Journal of

Applied Chemistry

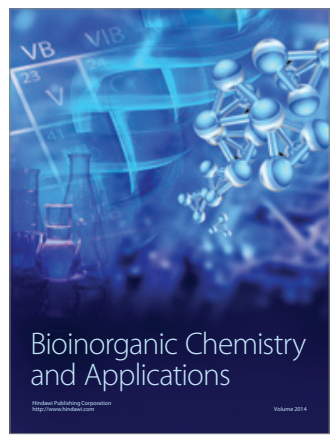

Inorganic Chemistry
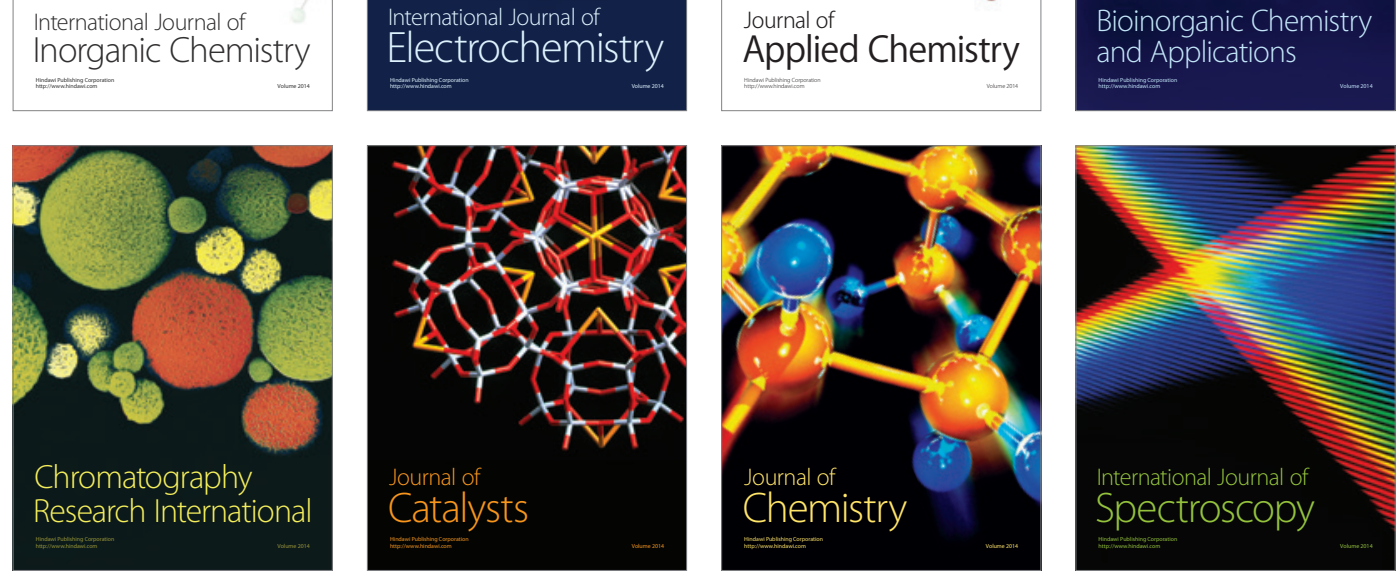